Review

\title{
Dual roles of yes-associated protein (YAP) in colorectal cancer
}

\author{
Chunlin Ou ${ }^{1,2,3}$, Zhenqiang Sun ${ }^{1,2,4,5}$, Shen $\mathbf{L i}^{1,2}$, Guiyuan Li ${ }^{1,2}$, Xiayu Li ${ }^{3, *}$ and Jian \\ $\mathrm{Ma}^{1,2,3, *}$ \\ ${ }^{1}$ Hunan Cancer Hospital and the Affiliated Cancer Hospital of Xiangya School of Medicine, Central South University, Changsha, \\ Hunan 410013, China \\ ${ }^{2}$ Key Laboratory of Carcinogenesis and Cancer Invasion of the Chinese Ministry of Education, Cancer Research Institute, \\ Central South University, Changsha, Hunan 410078, China \\ ${ }^{3}$ Hunan Key Laboratory of Nonresolving Inflammation and Cancer, The Third Xiangya Hospital, Central South University, \\ Changsha, Hunan 410013, China \\ ${ }^{4}$ Department of Anorectal Surgery, The First Affiliated Hospital of Zhengzhou University, Zhengzhou, Henan 450052, China \\ ${ }^{5}$ Department of Gastrointestinal Surgery, Tumor Hospital of Xinjiang Medical University, Urumqi, Xinjiang 830011, China \\ "These authors contributed equally to this work \\ Correspondence to: Jian Ma, email: majian@csu.edu.cn \\ Xiayu Li, email: lixiayu@163.com
}

Keywords: colorectal cancer, Yes-associated protein, tumour biomarker, stemness maintenance, inflammation

Received: July 07, $2017 \quad$ Accepted: July 30, $2017 \quad$ Published: August 11, 2017

Copyright: Ou et al. This is an open-access article distributed under the terms of the Creative Commons Attribution License 3.0 (CC BY 3.0 ), which permits unrestricted use, distribution, and reproduction in any medium, provided the original author and source are credited.

\section{ABSTRACT}

Yes-associated protein (YAP) is a downstream effector molecule of a newly emerging tumour suppressor pathway called the Hippo pathway. YAP is a transcriptional co-activator and mis-expressed in various cancers, including colorectal cancer (CRC). Accumulating studies show that the high expression of nuclear YAP is linked with tumour progression and decreased survival. Nuclear YAP can interact with other transcription factors to promote cancer cell proliferation, apoptosis, metastasis and maintenance of stemness. Therefore, YAP has the potential to be a tumour biomarker or therapeutic target for CRC. However, recently, a number of studies have supported a contradictory role for YAP as a tumour suppressor, demonstrating inhibition of the tumorigenesis of $\mathrm{CRC}$, involvement in promoting cell apoptosis, and inhibiting the maintenance of intestinal stem cells and inflammatory activity. In these studies, high expression of YAP was highly correlated with worse survival in CRC. In this review, we will comprehensively summarize and analyse these paradoxical reports, and discuss both the oncogenic and tumour suppressor functions of YAP in the differential status of CRC progression. Further investigation into the mechanisms responsible for the dual function of YAP will be of great value in the prevention, early diagnosis, and therapy of CRC.

\section{INTRODUCTION}

Colorectal cancer (CRC) is the most common malignant tumour of the digestive system and the fourth leading cause of cancer-related death worldwide [1]. According to the Global Cancer Statistic, there were 1.36 million new cases of colorectal cancer, making CRC malignant tumors have the third-highest incidence in the world, ranking third in males and second in females; CRC caused approximately 0.69 million death, ranking fourth among malignant tumors, and increases in mortality rates are still occurring in developed countries [2-5]. However, the five-year survival time of CRC patients is increasing in some populations and varies across countries, ranging from $4.3 \%$ to $5.3 \%$ for men and from $2.7 \%$ to $4.9 \%$ for women. Although significant progress has been made in understanding and therapy of CRC, morbidity and mortality rates remain high because cancer recurrence and metastasis are common [6-9]. Therefore, screening and early detection of CRC is an important clinical strategy for improving long-term survival [2, 10]. Currently, clinical screening of CRC commonly involves endoscopic 
screening, particularly colonoscopy [11-15]; however, there are several problems in this approach, including poor patient compliance, with family history [16, 17], inconvenience, expense and risk [18-20]. Therefore, it is urgent to search for effective strategies for early diagnosis, detection of recurrence, and monitoring of progression in CRC [10].

A tumour biomarker is defined by the National Institutes of Health's Biomarkers Definitions Working Group as "a characteristic that is objectively measured and evaluated as an indicator of normal biologic processes, pathogenic processes, or pharmacologic responses to a therapeutic intervention" [21]. The expression of tumour biomarkers in cancer cells and tissues can reflect the progression and prognosis of malignant tumour [22]. Yes-Associated Protein (YAP) is a downstream effector molecule of a newly emerging tumour suppressor pathway called Hippo [23, 24]. An increasing number of studies suggest that YAP is an oncogenic transcription coactivator highly expressed in various tumors that can regulate tumour development and progression $[25,26]$. However, recently, a number of studies have supported the contradictory view that YAP can be a tumour suppressor because it can function to inhibit the tumorigenesis of CRC through effects on cell growth, apoptosis, maintenance of stemness, and inflammatory responses. In addition, decreased expression of YAP was highly correlated with decreased survival in CRC. This review will comprehensively summarize and analyse these paradoxical reports, and discuss both the oncogenic and tumour suppressor functions of YAP in CRC progression. Further investigation into the mechanisms responsible for the dual function of YAP will be of great value in the prevention, early diagnosis, and therapy of CRC.

\section{Molecular structures and function of Hippo/YAP}

YAP was originally identified in chickens as a binding protein of nonreceptor tyrosine kinase YES1 in 1994 [27], which was considered the mammalian orthologue of Drosophila Yorkie (Yki) [28]. The human YAP gene maps to chromosome 11 at the 11q22.1 locus. YAP is a proline-rich phosphoprotein containing a prolinerich domain, WW domain, coiled-coil (C-C) domain, and a PDZ-binding motif formed by the four $\mathrm{C}$-terminal amino acids (LTWL) [29-31]. The WW domain is conserved in different YAP protein family members. YAP exists in two isoforms: an isoform with one WW domain is called YAP1 and another isoform with two WW domains is called YAP2 $[32,33]$. YAP was originally identified by its association with the YES Src tyrosine kinase and has been shown to be a transcription factor whose cytoplasmic/ nuclear shuttling is controlled by post-translational phosphorylation events $[34,35]$. As the gene locus of YAP is frequently amplified in various human cancers $[25,36$, 37 , the elevated expression of YAP has been consistently observed in multiple types of human cancers, for example non-small-cell lung cancer (NSCLC) [38, 39], gastric cancer $[40,41]$, urothelial carcinoma of the bladder (UCB) $[42,43]$, esophageal squamous cell carcinoma (ESCC) $[44,45]$, ovarian cancer $[46,47], \mathrm{CRC}[48,49]$, and cervical cancer $[50,51]$.

The Hippo pathway is an important signalling pathway in controlling organ size and stem cell self-renewal, and regulates tissue homeostasis, cell proliferation, and apoptosis $[37,52]$. Furthermore, recent studies have demonstrated that the Hippo pathway is associated with tumorigenesis and tumour progression and dysfunction of this pathway often contributes to cancer development and tumorigenesis [25, 53, 54]. The components of the mammalian Hippo pathway include manmalian Ste20-like kinase (MST1 and MST2, hippo homologues), large tumour suppressor kinases (LATS1 and LATS2, WTS homologues), Yes-associated protein (YAP), and transcriptional co-activator with PDZbinding motif (TAZ) $[55,56]$. YAP and TAZ have similar structures and functions $[26,57]$ and are the main effector molecules downstream of the Hippo pathway, which act as transcriptional co-activators. Briefly, when this pathway is activated in mammals, MST1/2 and LATS1/2 kinases cooperate with adaptor proteins containing Salvador 1 (SAV1) and MOB kinase activator $1 \mathrm{~A} / \mathrm{B}(\mathrm{MOB} 1 \mathrm{a} / \mathrm{b})$ to phosphorylate and inhibit YAP localized in the nucleus [58-60]. Cytoplasmic YAP is phosphorylated on the Serine127 site (corresponding to mouse S112) by LATS1/2 to bind 14-3-3 site in cytoplasm, subsequently inducing cytoplasmic degradation as a complex of $\mathrm{p}^{\mathrm{S} 127}$-YAP/14-3-3 [61]. However, when the tissue microenvironment changes or cells are stimulated by extracellular or intracellular signals, for example changes in cell polarity, cell-cell contact, mechanical cues, cellular energy status, and ligands of G-protein-coupled receptors(GPCR) [24], the Hippo pathway is inactivated and YAP becomes hyperactivated. As YAP cannot bind DNA directly and must interact with DNA-binding transcription factors, hyperactivated YAP enters the nucleus to bind members of the TEA domain/Transcription Enhancer Factor (TEAD) family $[62,63]$ or other transcription factors, including RUNX1/2, Smad, ErbB4, and p63/p73, and induces expression of a series of target genes (e.g. AREG, $C T G F$, Cyr61) [23, 64]. Interestingly, Hippo pathway inactivation has been observed in multiple tumors, and elevated expression of YAP has been observed in the nuclei of cancer cells. In this context, YAP can act as a transcriptional co-activator interacting with other transcription factors to regulate cancer cell proliferation, metastasis, stem cell attributes, and patient prognosis.

\section{Crosstalk of Hippo/YAP with other pathways}

The progression and development of cancer is a complex process involving in multiple factors and 
stresses, and is also widely attributed to dysfunction of cellular signalling pathways. YAP is a transcriptional co-activator that is negatively regulated in the Hippo signalling pathway $[65,66]$. Recent studies have demonstrated that the Hippo/YAP pathway can crosstalk with other signalling pathways to regulate a series of biological functions in cancer, which is greatly depends on the important role of YAP that is not only mediated by the upstream signal molecule, but can also regulate a series of targets via interacting with transcription factors. By analysing studies published in recent years, we can summarize a complex regulatory network in which YAP is involved in a series of signalling pathways (Figure 1), such as those involving TGF- $\beta / \operatorname{SMAD}[67,68]$, Wnt/ $\beta$ catenin $[69,70]$, epidermal growth factor receptor (EGFR) [39, 71], PI3K-AKT [72, 73], NF-кB [69, 74], Sonic Hedgehog (Shh) [75, 76], mTOR [77, 78], IL6 receptor (IL-6R) [79, 80], GPCR [81, 82], and Notch [83, 84].

Hippo/YAP regulates many biological and pathological features via crosstalk with other signalling pathways, including control of organ size and tissue homeostasis, cell proliferation and apoptosis, and tumorigenesis. Tumaneng et al. [85] demonstrated that YAP inhibits PTEN translation by activating the expression of miR-29, and finally activates the mTOR pathway to regulate organ size. Avruch et al. [86] showed that YAP overexpression promotes colon cancer cell proliferation by synergizing with $\mathrm{Wnt} / \beta$-catenin signalling. However, Imajo et al. [87] demonstrated that YAP interacts with $\beta$-catenin directly and restricts $\beta$-catenin nuclear translocation, thereby inhibiting the activation of WNT signaling. The phenomenon could be founded the crosstalk of Hippo/YAP with TGF- $\beta /$ SMAD signalling pathways. Pefani et al. reported [67] that TGF- $\beta$ facilitates the YAP/SMAD2 nuclear translocation via targeting Hippo pathway scaffold RASSF1A. Nevertheless, a study by Sun [68] had a contradictory result, demonstrated that YAP inhibits smad3 signaling to promote the survival and self-renewal of tumor initiating cells (TICs) in breast cancer. Lapi et al. [88] reported that p73/YAP directly activated promyelocytic leukaemia (PML) gene transcription during the apoptotic response, and this activity is under the negative control of the protooncogenic Akt/PKB kinase. The activation of the Notch signalling pathway is an important pathway for inducing intestinal epithelial regeneration [89]. Camargo et al. [90] revealed that YAP overexpression can activate Notch signalling and c-secretase inhibition, thereby preventing YAP-induced intestinal dysplasia in the intestine; however, a study by Zhou [91] had a contradictory result, demonstrating that the loss of YAP would impair DSSinduced intestinal regeneration by inactivating the Notch pathway. In addition, Fernandez et al. [76] found that YAP functions as a stimulator of cell proliferation and an inhibitor of differentiation possibly downstream of Sonic hedgehog pathway in neural stem cells. Urtasun et al. [92] illustrated that the epidermal growth factor receptor (EGFR) signalling system in human hepatocellular

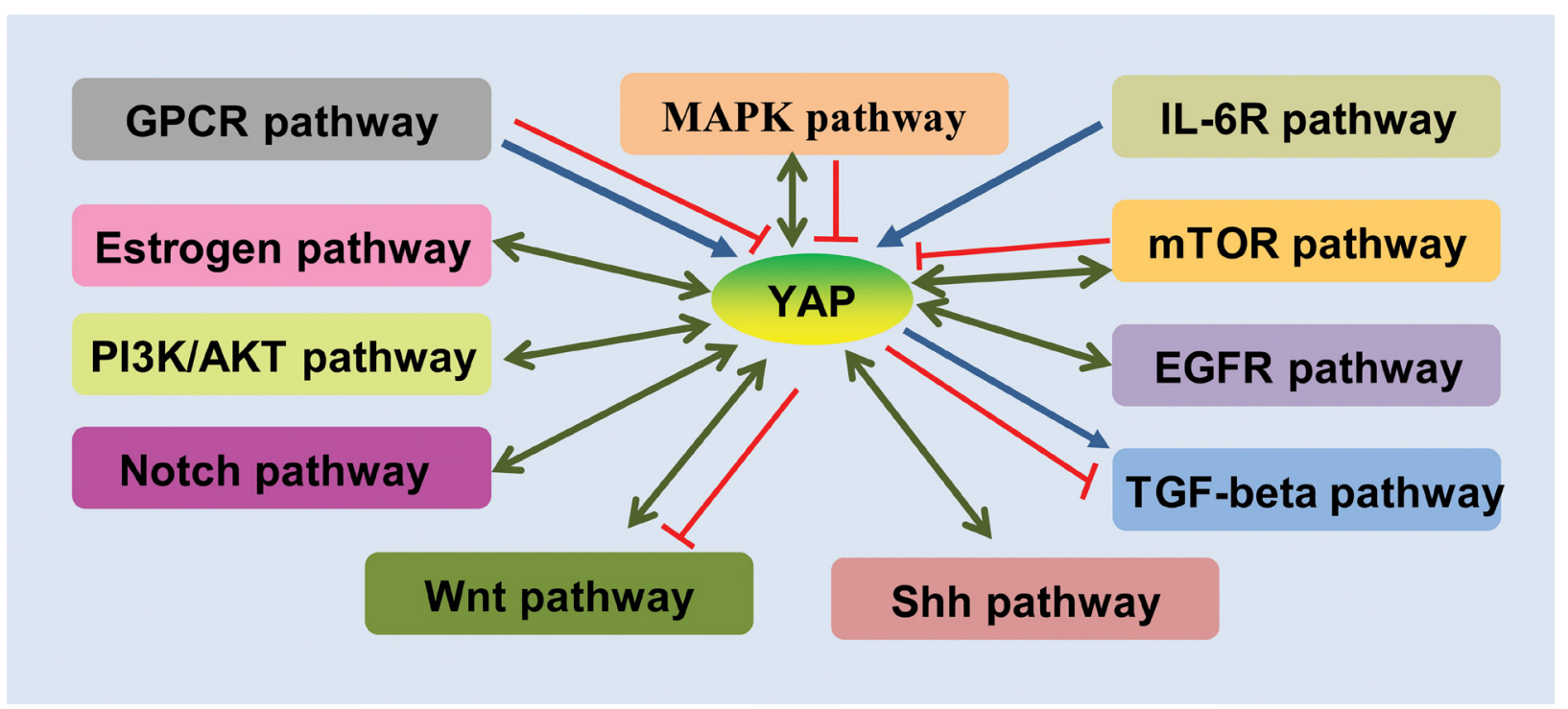

Figure 1: Schematic demonstration of the crosstalks of YAP with other pathways. GPCR pathway activates or inhibits the YAP; Estrogen pathway inhibits YAP and YAP activates Estrogen pathway; PI3K/AKT pathway activates YAP and YAP also activates PIK/AKT pathway; Notch pathway activates YAP and YAP also activates PIK/AKT pathway; Shh pathway activates YAP and YAP also activates shh pathway; Wnt pathway activates YAP and YAP activates or inhibits Wnt pathway; YAP activates or inhibits TGF-beta pathway; EGFR pathway activates YAP and YAP also activates EGFR pathway; mTOR pathway activates or inhibits YAP and YAP activates mTOR pathway; IL-6R pathway activates YAP; MAPK pathway activates or inhibits YAP and YAP activates MAPK pathway. In this diagram, the symbol "— "represents promoted; the symbol "—_ "represents inhibited; and the symbol " $\longleftrightarrow$ " represents inter-promoted. GPCR, G protein coupled receptors; GPCR, G-protein-coupled receptors; EGFR, epidermal growth factor receptor; Shh, Sonic Hedgehog; PI3K, phosphoinositide 3-kinase. 
carcinoma (HCC) cells cross-talks with the oncoprotein YAP. Moreover, He et al. [93] demonstrated that YAP can induce the expression of EGFR to control ovarian cancer initiation and progression.

\section{The dual roles of YAP in CRC cells}

\section{YAP as an oncogene}

In mammals, the Hippo/YAP pathway is important in regulating the balance between cell regeneration and proliferation [94]. When the Hippo pathway is dysregulation or inactivated, YAP will be dephosphorylated, thereby translocating into the nucleus to function as a transcriptional co-activator. Nuclear YAP can act as an oncogene that enhances invasion and proliferation and suppresses apoptosis. More than $85 \%$ of the YAP protein in normal tissue and cells is found in the cytoplasmic fraction, as determined by immunochemistry (IHC) [95]. However, nuclear YAP overexpression is frequently found in cancer tissues [96-101], including CRC $[49,102,103]$. The molecular mechanism of YAPmediated CRC regulation is associated with YAP protein phosphorylation and subcellular localization [104]. Konsavage et al. [105] demonstrated that YAP was found in the cytoplasm of the HCT116, SW620, SW480, RKO, LS174T, and HT29 CRC cell lines, and YAP gene silencing in SW620 (colon adenocarcinoma) and HCT116 (metastatic CRC) cell lines resulted in reduced growth of colonies in soft agar. Similarly, Wang et al. [106] revealed that YAP expression was highest in HCT116, LS174T, LOVO, SW480 and SW620 in CRC cell lines, and the capacity for proliferation, metastasis, and invasion was dramatically reduced by silencing YAP expression in HCT116 CRC cells. Furthermore, Vigneron et al. [107] showed that cytoplasmic apoptosis-stimulating protein of p53 1(ASPP 1) could inhibit the apoptosis of HCT116 CRC cell lines by suppressing the phosphorylation of YAP and enhancing nuclear accumulation of YAP. In addition, YAP has been identified as driver gene for inducing epithelial-mesenchymal transition (EMT), which may contribute to cancer invasion and metastasis [108-110]. YAP interacts with transcription factor TEAD to induce the multiple downstream targets associated with EMT gene expression $[63,111]$. At present, a number of studies have revealed that YAP overexpression is closely related to the EMT of many cancers, such as gastric cancer [112], breast cancer [113], and pancreatic cancer [114]. Some studies have also suggested that YAP is associated with EMT in CRC. Zhao et al. [115] reported that E2A suppresses EMT of CRC cells by inhibiting expression of YAP, which is a downstream target of E2A. In addition, Shao et al. [108] indicated that YAP signalling functionally substitutes for oncogenic KRAS in KRAS-dependent colon cancer cells to regulate the EMT via activation of the transcription factor FOS.

\section{YAP as a tumour suppressor gene}

Although YAP usually functions as an oncogene, abundant literature supports the idea that YAP functions as a tumour suppressor in various cancers, for instance head and neck cancers (HNC) [116], breast cancer [117119], haematological cancers [120], and CRC [121]. YAP's function as a tumour suppressor depends on the specific tissues involved $[120,122]$. In CRC, YAP has been shown to induce apoptosis in response to DNA damage by enhancing p73 transcription factor function in the promoters of apoptotic genes [34, 88, 118, 123]. Matallanas et al. [117] recently reported that RASSF1A can regulate $\mathrm{p} 73$-mediated apoptosis by alleviating YAP cytoplasmic retention, indicating that YAP might play a critical role in tumour suppression. Furthermore, Levy et al. [121] found that in HCT116 CRC cell line, DNA damage downregulates the ubiquitin $\mathrm{E} 3$ ligase Itch protein level that can mediate ubiquitination of p73, whereas YAP competes with Itch for binding to p73 to suppress p73 accumulation and induction of apoptosis by cisplatin treatment. Other studies have shown that YAP plays a tumour suppressor role by promoting cell death. Ehsanian et al. [116] demonstrated that overexpression of nuclear YAP causes cell death in HNC cell line. Francesca et al. [120] revealed that low nuclear YAP expression can result in evasion of cell death in the NCI-H929 cell line. Taken together, simply analysing the expression or distribution of YAP cannot be used to determine a therapeutic strategy in $\mathrm{CRC}$, because if YAP can reduce cell proliferation and induce cell apoptosis and death in $\mathrm{CRC}$, it implies that YAP activation could be beneficial in the treatment of CRC.

\section{The dual roles of YAP in intestinal stem cells}

The intestinal epithelium is a monolayer of tightly linked columnar cells [124] with the capacity for rapid self-renewal; it is organized into a crypt-villus unit in which proliferating cells are confined to the crypts, areas of proliferation composed of intestinal stem cells (ISCs) and its daughter-cells [125-127]. Cellular differentiation occurs when the cells move up to the villus tip [128]. ISCs are usually located at the bottoms of crypts and ensure maintenance of the tissue, which can be defined by two essential features, longevity and multipotency $[129,130]$, and are responsible for this constant selfrenewal throughout the lifetime [131]. Studies show that cancer stem cells (CSCs) are closely associated with tumorigenesis and poor prognosis of cancer patients $[132,133]$. CSCs are defined as a rare cell population in cancer, and are considered as the origins of tumors, based on histological observations. CSCs display the ability to regulate self-renewal and maintain tumour growth and heterogeneity [130, 134]. Recent studies have revealed that ISCs can act as the cells of origin for intestinal cancer 
$[135,136]$, which implies that CSCs originate from ISCs in intestinal crypts. Therefore, further investigation into the mechanisms responsible for the function of ISCs will be of great value to study the pathogenesis of CRC to develop new therapeutic targets.

Recent studies have demonstrated that Hippo/YAP signalling plays an important role in the maintenance of stemness and tissue homeostasis [137-139]. Moreover, it has previously been shown that the YAP protein is primarily localized to the crypt base, and is absent from villi $[90,140]$, which suggests that YAP may maintain the lack of differentiation of stem cells via binding to the TEAD transcription factor [141]. However, recent studies have shown that YAP has a dual role in regulatory ISCs, which regulate both stem cell proliferation and differentiation. On the one hand, YAP plays a critical role in the maintenance and expansion of undifferentiated ISCs during regeneration. In other words, YAP hyperactivation expands intestinal progenitor/stem cells, while YAP deletion impairs regeneration in intestines damaged with dextran sodium acetate [90, 140]. Camargo et al. [90] showed that ubiquitous overexpression of YAP-S127A in mouse tissues results in loss of differentiation markers and expansion of an undifferentiated cell population in the mouse intestine, whereas Patel et al. [142] showed that YAP can stimulate Notch pathway, which blocks differentiation to suppress the generated ISC tumors. On the other hand, YAP can induce ISC differentiation and restrict ISC expansion during regeneration. Zhou et al. [91] showed that YAP nuclear overexpression promotes the hyperproliferation of ISCs and inhibits differentiation due to activation of Notch signalling. Moreover, YAP can dampen Wnt/ $\beta$-catenin signalling [143, 144], which is important for the regulation of stem cells [145]; however, YAP nuclear localization is correlated with active Wnt signalling whereas cytoplasmic localization inhibits the Wnt pathway [122]. Barry et al. [122] further showed that YAP restricts the expansion of ISCs as well as critical components of the stem cell niche through suppression of WNT signalling, because YAP interacts with Dishevelled (DVL) $[146,147]$ to antagonize Wnt signalling and restrict ISC expansion. Taken together, this evidence supports that YAP not only promotes ISC proliferation but also induces ISC differentiation. Together, these studies provide strong evidence that YAP1 functions as a stem cell regulator and imply that YAP plays important roles in maintaining stemness and tissue homeostasis.

\section{The dual roles of YAP in CRC-associated inflammation response}

Cancer has been considered as a process of tissue repair dysregulation as well as being called "Wounds That Never Heal" [148]. Mantovani [149] reported that inflammation continually accelerates the "inflammation- cancer chain" in tumorigenesis, which may eventually evolve into "nonresolving inflammation-related cancer." To some degree, the relationship between cancer and inflammation has been confirmed. Epidemiologic evidence suggests that approximately $25 \%$ of all human cancer worldwide may be caused by inflammation $[150,151]$. In addition, inflammatory cells that can infiltrate tissue are always found in the cancer microenvironment. In tumorigenesis, inflammatory cells and molecules influence almost every aspect of cancer, including the formation of the cancer microenvironment [152], invasion/metastasis [153], and immune escape [154-156]. Consequently, biologically malignant inflammation is regarded as "the seventh characteristic of tumors" [149, 157-159].

Recent studies have demonstrated that inflammation plays a key role in the development and progression of CRC [160-162]. YAP plays a vital role in inflammationinduced cancer because it can act as a transcriptional co-activator interacting with other transcription factors to modulate expression of inflammation-associated factors. However, YAP not only induced inflammation, but also reduced inflammation according to the function of inflammation-associated factors. Yamada et al. [163] and $\mathrm{Li}$ et al. [164] showed that the biliary mitogen IL33 facilitates oncogene-induced cholangiocarcinoma (CCA) in mice through constitutively activating AKT and YAP oncogenes. Taniguchi et al. [80] have shown that IL-6 family members can be activated upon receptor engagement to phosphorylate YAP and induce its stabilization and nuclear translocation in CRC cell lines, promoting inflammatory bowel diseases (IBD) and CRC. $\mathrm{NF}-\kappa \mathrm{B}$ is an important mediator of inflammation [165], pathogenesis of intestinal inflammation, and inflammatory bowel disease (IBD) [166]. There is a negative correlation between YAP and NF- $\kappa \mathrm{B}$ signalling pathway. For instance, Gao et al. [167] demonstrated that knockdown of the expression of $Y A P$ by shRNA interference increases the luciferase activities of AP-1 and NF- $\kappa$ B in 293T cells, inducing expression of various target genes related to proliferation, angiogenesis, apoptosis and inflammation. In addition, Gordon et al. [74] reported that the tyrosine phosphorylation of YAP can induce the expression of proapoptotic genes to drive intestinal epithelial apoptosis. On the other hand, the tyrosine phosphorylation of YAP can restrict $\mathrm{NF}-\kappa \mathrm{B}$-dependent inflammation to promote recovery from inflammation-induced injury and maintain epithelial homeostasis. Furthermore, Kim et al. [48] showed that the activated YAP1 not only promoted colon regeneration after colitis, but also induced the proliferation of colon cancer cell lines in mice. Similarly, Huang et al. [168] demonstrated that the deletion of YAP increased astrocytic activation in culture and in vivo by hyperactivating the JAK-STAT inflammatory pathway, and negatively controlled neuroinflammation through the YAP-SOCS pathway. 


\section{Clinical relevance in $\mathrm{CRC}$}

\section{Expression of YAP as prognostic factors in CRC}

Overexpression of nuclear YAP has been observed in multiple types of human cancers [38-51] and is significantly associated with worse overall survival [46, 169-171]. In our previous study, Sun et al. [172] showed through meta-analysis of 21 studies that YAP overexpression was closely associated with adverse effects on overall survival (OS) and disease free survival (DFS) in numerous cancers. As mentioned, the expression of YAP in most types of cancers is higher than that in the corresponding normal tissues or cells. Studies have shown that the expression of YAP is highly correlated with the pTNM stage, nodal status, and tumour status of CRC, and that nuclear YAP overexpression was closely associated with worse overall survival [105, 106, 173-175]. Wang et al. [175] demonstrated that nuclear YAP overexpression was observed in approximately $52.5 \%$ of 139 CRC cases. Similarly, Konsavage et al. [105] reported that $86 \%$ of 36 primary CRC tumors scored positively for nuclear localization of YAP. Consistent with a study by Wang et al. [106], our previous study [102] showed that high expression of YAP is closely associated with lymph node metastasis and strongly linked to worse overall survival in CRC.

However, other reports demonstrating losses of expression of nuclear YAP in various cancers, including HNSCC [116], breast cancer [118, 119], haematological cancers [120], and CRC [121], demonstrate that contradictory reports exist on the expression of YAP in cancers including CRC. Barry et al. [122] showed that loss of YAP expression was associated with high grade tumors and stage IV cancer by evaluating YAP expression in a cohort of 672 CRC samples using immunohistochemistry, which may imply that YAP may act as a tumour suppressor in human CRC. Similarly in breast cancer, Kim et al. reported that stromal YAP and pYAP expression in breast cancer was associated with shorter DFS and OS [176]. Taken together, it is unclear how YAP can serve as a prognostic marker for CRC progression. Therefore, it is necessary to clarify the relationship between the expression of YAP and its clinical implications in CRC, which will aid in a better understanding the functions and roles of YAP in the development and progression of CRC.

\section{The therapeutic strategies for YAP in CRC}

Despite tremendous progress in CRC therapy, the morbidity and mortality caused by CRC is still high worldwide. Encouragingly, numerous studies showed that therapeutic efficacy for CRC patients could be improved by screening and early detection of CRC followed by timely intervention with surgery, chemoradiotherapy and targeted therapy. However, it was noted that the ideal tumour marker-described as being able to identify patients with an extended risk of fast progression or early recurrence after operation when compared with other patients of the same age, disease stage and other characteristics - is still lacking in CRC therapy. Endoscopic screening carries a certain degree of risk [16-20]. Therefore, it is urgent to search for the ideal molecular markers and drug targets for CRC.

Small-molecule therapeutics are currently the main strategy for personalized treatment of advanced cancer [104]. Because the Hippo pathway is evolutionarily conserved, the core molecules of the Hippo pathway are rarely mutated. YAP may be a potential target for smallmolecule modulators. These small-molecule modulators of YAP can be classified into three categories (Figure 2): (1) those regulating the upstream molecules of YAP, thereby effecting YAP-TEAD transcriptional activity, such as C19 [177], XMU-MP-1 [178], 9E1 [179], Latrunculin A/B [180], cytochalasin D [181], Blebbistatin [182], Erlotinib [183], Lapatinib [184], Wortmannin [71], BX795 [71] and the GPCR agonists(e.g. Epinephrine, Glucagon, Dihydrexidine [180]); (2) those modulating the phosphorylation of YAP and blocking YAP nuclear translacation, such as Dobutamine [185]; (3) those directly inhibiting YAP interact with TEAD1, directly targeting YAP, such as Verteporfin [186], VGLL4-mimicking peptide [187]. Fortunately, therapies targeting YAP have been breakthroughs in many cancers. For example, Brodowska et al. reported that the photosensitizer Verteporfin (VP) can inhibit YAP-TEAD transcriptional activity, thereby suppressing retinoblastoma(Rb) cell growth [186]. Similarily, Jiao et al. [187] demonstrated that a peptide mimicking VGLL4 functions as a physical antagonist of YAP and blocks YAP oncogenic activity at the transcriptional level in gastric cancer, which may provide an option for therapy. However, there have been few reports of small-molecule modulators of YAP being applied in treatment of CRC. Recent studies examining YAP in CRC have suggested that YAP may act synergistically with chemotherapy drugs. Lee et al. [174] demonstrated that the group of patients with activated YAP in CRC (AYCC) had slightly more advanced disease and much shorter survival rates than another group of patients with inactivated YAP1 in CRC. YAP activation was significantly associated with poor response to cetuximab therapy. Furthermore, Touil et al. [188] found that YAP could be a potential molecular target in dormant micrometastases during 5FU chemotherapy in colon cancer cells. Similarly, Huang et al. [48] showed that the treatment of ovatodiolide in combination with 5-FU significantly suppressed YAP1 oncogenic pathways to inhibit M2 TAM generation and the tumorigenesis of CRC. With regards to other types of cancers, Wang et al. [189] reported that simvastatin induced cancer cell growth arrest and decreased nuclear YAP by interfering with protein geranylgeranylation in breast cancer, and [190] illustrated that the activation of YAP can increase cell proliferation and methotrexate/doxorubicin resistance 
in osteosarcoma cells. We speculate that the reason for limited clinical application of small-molecule modulators of YAP is because it is difficult to determine whether inhibiting or stimulating the expression of YAP would be a more suitable strategy, due to both the oncogenic and tumour suppressor roles of YAP observed in CRC. Therefore, the role of YAP should be further explored.

\section{CONCLUSIONS AND FUTURE PERSPECTIVES}

In the last several years, the rapid progress of Hippo/ YAP pathway research has resulted in a broad signalling map being built, and many studies have demonstrated that the effector molecule YAP is closely associated with the physiological organ size control and pathological progression of CRC. Tumour biomarkers have attracted increasing attention as novel tools in cancer diagnosis and therapy. Currently, it is a boom time for therapies targeting Hippo/YAP in CRC. In many studies, YAP has displayed the characteristics of a tumour biomarker because it is overexpressed in many cancers, promotes the development and progression of cancers, is easily detected in tissue, and is associated with prognosis. However, a number of studies have suggested that YAP plays a role as a tumour suppressor in the development and progression of CRC. By comprehensively analysing relevant research, we speculate that this paradox can be explained in four ways: (1) As an effector molecule of the Hippo signalling pathway, YAP can act as a bridge in crosstalk with other signalling pathways(e.g. TGF- $\beta / \mathrm{SMAD}$, Wnt/ $\beta$-catenin), and can modulate the activity level of these pathways via positive or negative regulation, depending on the type of tissues or cells; (2) YAP activity is regulated by the upstream tumour suppressor signalling of the Hippo pathway; on the other hand, YAP can transcriptionally modulate the upstream tumour suppressor molecules of the Hippo pathway (e.g. Lats2 [191], NF2 [192]) to inhibit CRC tumorigenesis; (3) In the different stages of CRC development and progression, the distribution of nuclear vs. cytoplasmic YAP

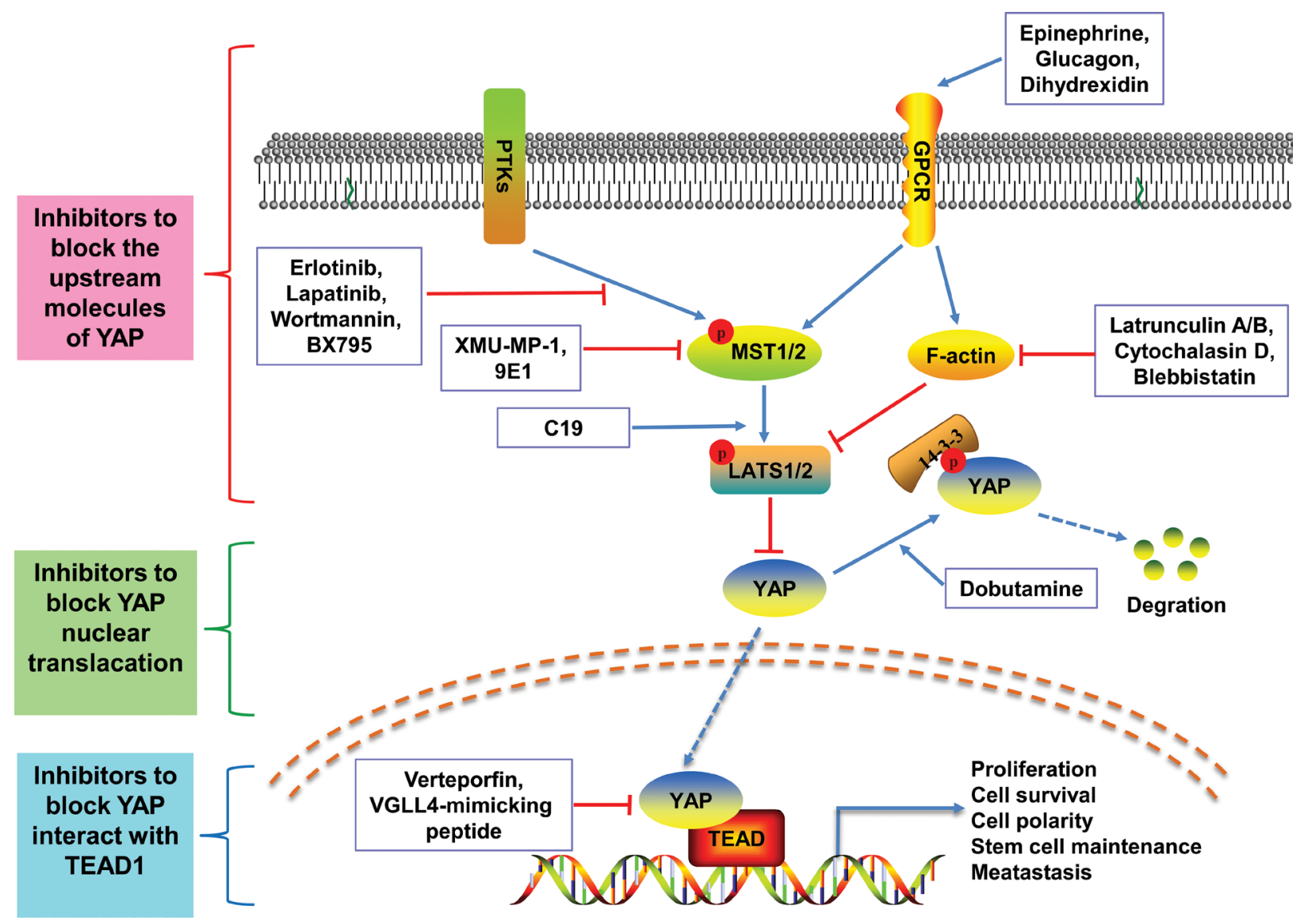

Figure 2: Schematic demonstration of the small-molecule modulators of YAP. These small-molecule modulators of YAP can be classified into three categories: (1) the red area represents those regulating the upstream molecules of YAP, as follows: C19 inhibits the activated of LATS1; XMU-MP-1 and 9E1 targets MST1/2; Latrunculin A/B, cytochalasin D and Blebbistatin directly inhibit F-actin; the GPCR agonists (e.g. Epinephrine, Glucagon, Dihydrexidine) activate LATS1/2; Erlotinib, Lapatinib, Wortmannin and BX795 inhibit the activated of MST1/2; (2) the green area represents those modulating the phosphorylation of YAP and blocking YAP nuclear translacation, such as Dobutamine; (3) the blue area represents those inhibiting YAP interaction with TEAD1 by directly targeting YAP, such as Verteporfin, VGLL4-mimicking peptide. 
expression and the phosphorylation level of cytoplasmic YAP change dynamically; (4) In poorly differentiated CRC tissue, although the expression of YAP is mainly localized to the nucleus, the transcriptional activity of YAP is suppressed because other nuclear molecules (e.g. T-cell lymphoma invasion and metastasis 1 (TIAM1) [193], IQ motif containing GTPase activating protein 1 (IQGAP1) [194]) bind to YAP and occupy its TEAD-binding domain; thus, YAP is unable to bind the transcription factor TEAD1 and regulate target gene expression [195]. The development and progression of CRC is a dynamic process, and the expression levels of some molecules differs in the different stages of CRC. This implies that YAP may change from a tumour inducer to a tumour suppressor under some conditions. Important goals for ongoing tumour biomarker studies include ensuring that patients receive the benefit of being exposed to as many active therapies as possible while minimizing any treatment-related morbidity. Therefore, greater understanding of the clinical roles and molecular mechanisms of YAP in CRC is required and will be of great value in the development of new molecular targets for drugs. With all these efforts, targeting YAP may become a promising therapeutic strategy for the treatment of CRC in the future.

\section{Abbreviations}

YAP, Yes-associated protein; CRC, colorectal cancer; CEA, carcinoembryonic antigen; CA19-9, carbohydrate antigen 19-9; NSCLC, non-small-cell lung cancer; UCB, urothelial carcinoma of the bladder; ESCC, esophageal squamous cell carcinoma; Yki, Yorkie; MOB1a/b, MOB kinase activator 1A/B; SAV1, Salvador 1; LATS1, large tumour suppressor kinases 1; LATS2, large tumour suppressor kinases 2; MST1, manmalian Ste20-like kinase 1; MST2, manmalian Ste20-like kinase 2; TEAD, TEA domain/Transcription Enhancer Factor; GPCR, G-proteincoupled receptors; EGFR, epidermal growth factor receptor; Shh, Sonic Hedgehog; PI3K, phosphoinositide 3-kinase; PDK1, phosphoinositide-dependent kinase; PML, promyelocytic leukaemia; HCC, hepatocellular carcinoma; IHC, immunochemistry; ASPP 1, apoptosis-stimulating protein of p53 1; EMT, epithelial-mesenchymal transition; HNC, head and neck cancers; ISCs, intestinal stem cells; CSCs, cancer stem cells; DVL, Dishevelled; CCA, cholangiocarcinoma; IBD, inflammatory bowel diseases; DFS, disease free survival; OS, overall survival; TIAM1, T-cell lymphoma invasion and metastasis 1; IQGAP1, IQ motif containing GTPase activating protein 1 .

\section{ACKNOWLEDGMENTS}

This work was supported by the National Natural Science Foundation of China (81472694, 81560385), China 111 Project (111-2-12), and the student innovation project of Central south university (2017zzts010).

\section{CONFLICTS OF INTEREST}

The authors declare no competing financial interest.

\section{REFERENCES}

1. Mármol I, Sánchez-de-Diego C, Pradilla Dieste A, Cerrada E, Rodriguez Yoldi MJ. Colorectal Carcinoma: A General Overview and Future Perspectives in Colorectal Cancer. Int J Mol Sci. 2017; 18.

2. Peters U, Bien S, Zubair N. Genetic architecture of colorectal cancer. Gut. 2015; 64:1623-1636.

3. Tamas K, Walenkamp AM, de Vries EG, van Vugt MA, Beets-Tan RG, van Etten B, de Groot DJ, Hospers GA. Rectal and colon cancer: Not just a different anatomic site. Cancer Treat Rev. 2015; 41:671-679.

4. Torre LA, Bray F, Siegel RL, Ferlay J, Lortet-Tieulent J, Jemal A. Global cancer statistics, 2012. CA Cancer J Clin. 2015; 65:87-108.

5. Ferlay J, Shin HR, Bray F, Forman D, Mathers C, Parkin DM. Estimates of worldwide burden of cancer in 2008: GLOBOCAN 2008. Int J Cancer. 2010; 127:2893-2917.

6. Siegel RL, Miller KD, Fedewa SA, Ahnen DJ, Meester RGS, Barzi A, Jemal A. Colorectal cancer statistics, 2017. CA Cancer J Clin. 2017; 67:177-193.

7. Siegel RL, Miller KD, Jemal A. Cancer Statistics, 2017. CA Cancer J Clin. 2017; 67:7-30.

8. Labianca R, Nordlinger B, Beretta GD, Brouquet A, Cervantes A; ESMO Guidelines Working Group. Primary colon cancer: ESMO Clinical Practice Guidelines for diagnosis, adjuvant treatment and follow-up. Ann Oncol. 2010; 21 Suppl 5:v70-v77.

9. Van Blarigan EL, Meyerhardt JA. Role of physical activity and diet after colorectal cancer diagnosis. J Clin Oncol. 2015; 33:1825-1834.

10. Jia S, Zhang R, Li Z, Li J. Clinical and biological significance of circulating tumor cells, circulating tumor DNA, and exosomes as biomarkers in colorectal cancer. Oncotarget. 2015; 6:42008-18. https://doi.org/10.18632/oncotarget.5788.

11. Doubeni CA, Corley DA, Quinn VP, Jensen CD, Zauber AG, Goodman M, Johnson JR, Mehta SJ, Becerra TA, Zhao WK, Schottinger J, Doria-Rose VP, Levin TR, et al. Effectiveness of screening colonoscopy in reducing the risk of death from right and left colon cancer: a large community-based study. Gut. 2016.

12. Nishihara R, Wu K, Lochhead P, Morikawa T, Liao X, Qian ZR, Inamura K, Kim SA, Kuchiba A, Yamauchi M, Imamura Y, Willett WC, Rosner BA, et al. Long-term colorectal-cancer incidence and mortality after lower endoscopy. N Engl J Med. 2013; 369:1095-1105.

13. Smith RA, Cokkinides V, Brawley OW. Cancer screening in the United States, 2012: A review of current American Cancer Society guidelines and current issues in cancer screening. CA Cancer J Clin. 2012; 62:129-142. 
14. Huang HY, Shi JF, Guo LW, Bai YN, Liao XZ, Liu GX, Mao AY, Ren JS, Sun XJ, Zhu XY, Wang L, Song BB, Du $\mathrm{LB}$, et al. Expenditure and financial burden for the diagnosis and treatment of colorectal cancer in China: a hospitalbased, multicenter, cross-sectional survey. Chin J Cancer. 2017; 36:41.

15. Bian J. Overuse of colorectal cancer screening services in the United States and its implications. Chin J Cancer. 2016; 35:88.

16. Jackson-Thompson J, Ahmed F, German RR, Friedman C. Descriptive epidemiology of colorectal cancer in the United States, 1998-2001. Cancer. 2006; 107:1103-1111.

17. Win AK, Macinnis RJ, Hopper JL, Jenkins MA. Risk prediction models for colorectal cancer: a review. Cancer Epidemiol Biomarkers Prev. 2012; 21:398-410.

18. DeBourcy AC, Lichtenberger S, Felton S, Butterfield KT, Ahnen DJ, Denberg TD. Community-based preferences for stool cards versus colonoscopy in colorectal cancer screening. J Gen Intern Med. 2008; 23:169-174.

19. Ling BS, Schoen RE, Trauth JM, Wahed AS, Eury T, Simak DM, Solano FX, Weissfeld JLl. Physicians encouraging colorectal screening: a randomized controlled trial of enhanced office and patient management on compliance with colorectal cancer screening. Arch Intern Med. 2009; 169:47-55.

20. Doubeni CA, Laiyemo AO, Young AC, Klabunde CN, Reed G, Field TS, Fletcher RH. Primary care, economic barriers to health care, and use of colorectal cancer screening tests among Medicare enrollees over time. Ann Fam Med. 2010; 8:299-307.

21. Biomarkers and surrogate endpoints: preferred definitions and conceptual framework. Clin Pharmacol Ther. 2001; 69:89-95.

22. Cooner WH. Definition of the ideal tumor marker. Urol Clin North Am. 1993; 20:575-579.

23. Yu FX, Zhao B, Guan KL. Hippo Pathway in Organ Size Control, Tissue Homeostasis, and Cancer. Cell. 2015; 163:811-828.

24. Meng Z, Moroishi T, Guan KL. Mechanisms of Hippo pathway regulation. Genes Dev. 2016; 30:1-17.

25. Zhao B, Li L, Lei Q, Guan KL. The Hippo-YAP pathway in organ size control and tumorigenesis: an updated version. Genes Dev. 2010; 24:862-874.

26. Moroishi T, Hansen CG, Guan KL. The emerging roles of YAP and TAZ in cancer. Nat Rev Cancer. 2015; 15:73-79.

27. Sudol M. Yes-associated protein (YAP65) is a proline-rich phosphoprotein that binds to the SH3 domain of the Yes proto-oncogene product. Oncogene. 1994; 9:2145-2152.

28. Huang J, Wu S, Barrera J, Matthews K, Pan D. The Hippo signaling pathway coordinately regulates cell proliferation and apoptosis by inactivating Yorkie, the Drosophila Homolog of YAP. Cell. 2005; 122:421-434.

29. Overholtzer M, Zhang J, Smolen GA, Muir B, Li W, Sgroi DC, Deng CX, Brugge JS, Haber DA. Transforming properties of YAP, a candidate oncogene on the chromosome 11q22 amplicon. Proc Natl Acad Sci U S A. 2006; 103:12405-12410.

30. Lorenzetto E, Brenca M, Boeri M, Verri C, Piccinin E, Gasparini P, Facchinetti F, Rossi S, Salvatore G, Massimino M, Sozzi G, Maestro R, Modena P. YAP1 acts as oncogenic target of 11q22 amplification in multiple cancer subtypes. Oncotarget. 2014; 5:2608-2621. https://doi.org/10.18632/ oncotarget. 1844.

31. Sudol M, Bork P, Einbond A, Kastury K, Druck T, Negrini M, Huebner K, Lehman D. Characterization of the mammalian YAP (Yes-associated protein) gene and its role in defining a novel protein module, the WW domain. J Biol Chem. 1995; 270:14733-14741.

32. Sudol M, Shields DC, Farooq A. Structures of YAP protein domains reveal promising targets for development of new cancer drugs. Semin Cell Dev Biol. 2012; 23:827-833.

33. Hwang JH, Pores FA, Faure N, Andrabi S, Adelmant G, Hahn WC, Marto JA, Schaffhausen BS, Roberts TM. Polyomavirus small $\mathrm{T}$ antigen interacts with yes-associated protein to regulate cell survival and differentiation. J Virol. 2014; 88:12055-12064.

34. Bertini E, Oka T, Sudol M, Strano S, Blandino G. YAP: at the crossroad between transformation and tumor suppression. Cell Cycle. 2009; 8:49-57.

35. Basu S, Totty NF, Irwin MS, Sudol M, Downward J. Akt phosphorylates the Yes-associated protein, YAP, to induce interaction with 14-3-3 and attenuation of p73-mediated apoptosis. Mol Cell. 2003; 11:11-23.

36. Steinhardt AA, Gayyed MF, Klein AP, Dong J, Maitra A, Pan D, Montgomery EA, Anders RA. Expression of Yesassociated protein in common solid tumors. Hum Pathol. 2008; 39:1582-1589.

37. Pan D. Hippo signaling in organ size control. Genes Dev. 2007; 21:886-897.

38. Guo J, Wu Y, Yang L, Du J, Gong K, Chen W, Dai J, Li $\mathrm{X}, \mathrm{Xi}$ S. Repression of YAP by NCTD disrupts NSCLC progression. Oncotarget. 2017; 8:2307-2319. https://doi. org/10.18632/oncotarget.13668.

39. Chaib I, Karachaliou N, Pilotto S, Codony Servat J, Cai X, Li X, Drozdowskyj A, Servat CC, Yang J, Hu C, Cardona AF, Vivanco GL, Vergnenegre A et al. Co-activation of STAT3 and YES-Associated Protein 1 (YAP1) Pathway in EGFR-Mutant NSCLC. J Natl Cancer Inst. 2017; 109.

40. Zhou Z, Zhu JS, Gao CP, Li LP, Zhou C, Wang H, Liu XG. siRNA targeting YAP gene inhibits gastric carcinoma growth and tumor metastasis in SCID mice. Oncol Lett. 2016; 11:2806-2814.

41. Ma LG, Bian SB, Cui JX, Xi HQ, Zhang KC, Qin HZ, Zhu $\mathrm{XM}$, Chen L. LKB1 inhibits the proliferation of gastric cancer cells by suppressing the nuclear translocation of Yap and beta-catenin. Int J Mol Med. 2016; 37:1039-1048.

42. Liu JY, Li YH, Lin HX, Liao YJ, Mai SJ, Liu ZW, Zhang ZL, Jiang LJ, Zhang JX, Kung HF, Zeng YX, Zhou FJ, Xie D. Overexpression of YAP 1 contributes to progressive 
features and poor prognosis of human urothelial carcinoma of the bladder. BMC Cancer. 2013; 13:349.

43. Ciamporcero E, Shen H, Ramakrishnan S, Yu Ku S, Chintala S, Shen L, Adelaiye R, Miles KM, Ullio C, Pizzimenti S, Daga M,Azabdaftari G, Attwood K et al. YAP activation protects urothelial cell carcinoma from treatmentinduced DNA damage. Oncogene. 2016; 35:1541-1553.

44. Muramatsu T, Imoto I, Matsui T, Kozaki K, Haruki S, Sudol M, Shimada Y, Tsuda H, Kawano T, Inazawa J. YAP is a candidate oncogene for esophageal squamous cell carcinoma. Carcinogenesis. 2011; 32:389-398.

45. Yeo MK, Kim SH, Kim JM, Huang SM, Kim MR, Song KS, Kim KH. Correlation of expression of phosphorylated and non-phosphorylated Yes-associated protein with clinicopathological parameters in esophageal squamous cell carcinoma in a Korean population. Anticancer Res. 2012; 32:3835-3840.

46. Cho SY, Kim K, Park MS, Jang MY, Choi YH, Han S, Shin HM, Chung C, Han HY, Yang JB, Ko YB, Yoo HJ. Expression of Yes-associated protein 1 and its clinical significance in ovarian serous cystadenocarcinoma. Oncol Rep. 2017; 37:2620-2632.

47. Xiao L, Shi XY, Zhang Y, Zhu Y, Zhu L, Tian W, Zhu BK, Wei ZL. YAP induces cisplatin resistance through activation of autophagy in human ovarian carcinoma cells. Onco Targets Ther. 2016; 9:1105-1114.

48. Huang YJ, Yang CK, Wei PL, Huynh TT, WhangPeng J, Meng TC, Hsiao M, Tzeng YM, Wu AT, Yen Y. Ovatodiolide suppresses colon tumorigenesis and prevents polarization of M2 tumor-associated macrophages through YAP oncogenic pathways. J Hematol Oncol. 2017; 10:60.

49. Ling HH, Kuo CC, Lin BX, Huang YH, Lin CW Elevation of YAP promotes the epithelial-mesenchymal transition and tumor aggressiveness in colorectal cancer. Exp Cell Res. 2017; 350:218-225.

50. He C, Mao D, Hua G, Lv X, Chen X, Angeletti PC, Dong J, Remmenga SW, Rodabaugh KJ, Zhou J, Lambert PF, Yang P, Davis JS, et al. The Hippo/YAP pathway interacts with EGFR signaling and HPV oncoproteins to regulate cervical cancer progression. EMBO Mol Med. 2015; 7:1426-1449.

51. Liu T, Liu Y, Gao H, Meng F, Yang S, Lou G. Clinical significance of yes-associated protein overexpression in cervical carcinoma: the differential effects based on histotypes. Int J Gynecol Cancer. 2013; 23:735-742.

52. Zhao B, Tumaneng K, Guan KL. The Hippo pathway in organ size control, tissue regeneration and stem cell selfrenewal. Nat Cell Biol. 2011; 13:877-883.

53. Harvey K, Tapon N. The Salvador-Warts-Hippo pathway an emerging tumour-suppressor network. Nat Rev Cancer. 2007; 7:182-191.

54. Chan SW, Lim CJ, Chen L, Chong YF, Huang C, Song $\mathrm{H}$, Hong W. The Hippo pathway in biological control and cancer development. J Cell Physiol. 2011; 226:928-939.

55. Zhao B, Lei QY, Guan KL. The Hippo-YAP pathway: new connections between regulation of organ size and cancer. Curr Opin Cell Biol. 2008; 20:638-646.
56. Harvey KF, Zhang X, Thomas DM. The Hippo pathway and human cancer. Nat Rev Cancer. 2013; 13:246-257.

57. Lei QY, Zhang H, Zhao B, Zha ZY, Bai F, Pei XH, Zhao $\mathrm{S}$, Xiong Y, Guan KL. TAZ promotes cell proliferation and epithelial-mesenchymal transition and is inhibited by the hippo pathway. Mol Cell Biol. 2008; 28:2426-2436.

58. Zhao B, Wei X, Li W, Udan RS, Yang Q, Kim J, Xie J, Ikenoue T, Yu J, Li L, Zheng P, Ye K, Chinnaiyan A, et al. Inactivation of YAP oncoprotein by the Hippo pathway is involved in cell contact inhibition and tissue growth control. Genes Dev. 2007; 21:2747-2761.

59. Felley-Bosco E, Stahel R. Hippo/YAP pathway for targeted therapy. Transl Lung Cancer Res. 2014; 3:75-83.

60. Heidary AE, Shiban A, Song S, Attisano L. MARK4 inhibits Hippo signaling to promote proliferation and migration of breast cancer cells. EMBO Rep. 2017; 18:420-436.

61. Zanconato F, Cordenonsi M, Piccolo S. YAP/TAZ at the Roots of Cancer. Cancer Cell. 2016; 29:783-803.

62. Yu FX, Guan KL. The Hippo pathway: regulators and regulations. Genes Dev. 2013; 27:355-371.

63. Zhao B, Ye X, Yu J, Li L, Li W, Li S, Yu J, Lin JD, Wang CY, Chinnaiyan AM, Lai ZC, Guan KL. TEAD mediates YAP-dependent gene induction and growth control. Genes Dev. 2008; 22:1962-1971.

64. Varelas X. The Hippo pathway effectors TAZ and YAP in development, homeostasis and disease. Development. 2014; 141:1614-1626.

65. Wang H, Du YC, Zhou XJ, Liu H, Tang SC. The dual functions of YAP-1 to promote and inhibit cell growth in human malignancy. Cancer Metastasis Rev. 2014; 33:173-181.

66. Liu AM, Xu MZ, Chen J, Poon RT, Luk JM. Targeting YAP and Hippo signaling pathway in liver cancer. Expert Opin Ther Targets. 2010; 14:855-868.

67. Pefani DE, Pankova D, Abraham AG, Grawenda AM, Vlahov N, Scrace S, O' Neill E. TGF-beta Targets the Hippo Pathway Scaffold RASSF1A to Facilitate YAP/SMAD2 Nuclear Translocation. Mol Cell. 2016; 63:156-166.

68. Sun JG, Chen XW, Zhang LP, Wang J, Diehn M. promotes the survival and self-renewal of breast tumor initiating cells via inhibiting Smad3 signaling. Oncotarget. 2016; 7:9692-9706. https://doi.org/10.18632/oncotarget.6655.

69. Perumal N, Perumal M, Kannan A, Subramani K, Halagowder D, Sivasithamparam N. Morin impedes Yap nuclear translocation and fosters apoptosis through suppression of Wnt/beta-catenin and NF-kappaB signaling in Mst1 overexpressed HepG2 cells. Exp Cell Res. 2017; 355:124-141.

70. Seo WI, Park S, Gwak J, Ju BG, Chung JI, Kang PM, Oh $\mathrm{S}$. Wnt signaling promotes androgen-independent prostate cancer cell proliferation through up-regulation of the hippo pathway effector YAP. Biochem Biophys Res Commun. 2017; 486:1034-1039. 
71. Fan R, Kim NG, Gumbiner BM. Regulation of Hippo pathway by mitogenic growth factors via phosphoinositide 3-kinase and phosphoinositide-dependent kinase-1. Proc Natl Acad Sci U S A. 2013; 110:2569-2574.

72. Wang C, Gu C, Jeong KJ, Zhang D, Guo W, Lu Y, Ju Z, Panupinthu N, Yang JY, Gagea MM, Ng PK, Zhang F, Mills GB. YAP/TAZ-Mediated Upregulation of GAB2 Leads to Increased Sensitivity to Growth Factor-Induced Activation of the PI3K Pathway. Cancer Res. 2017; 77:1637-1648.

73. Zhang Y, Yuan J, Zhang X, Yan F, Huang M, Wang T, Zheng $\mathrm{X}$, Zhang M. Angiomotin promotes the malignant potential of colon cancer cells by activating the YAP-ERK/PI3KAKT signaling pathway. Oncol Rep. 2016; 36:3619-3626.

74. Gordon M, El-Kalla M, Zhao Y, Fiteih Y, Law J, Volodko N, Anwar-Mohamed A, El-Kadi AO, Liu L,Odenbach J, Thiesen A, Onyskiw C, Ghazaleh HA, et al. The tumor suppressor gene, RASSF1A, is essential for protection against inflammation -induced injury. PLoS One. 2013; 8:e75483.

75. Dey A, Robitaille M, Remke M, Maier C, Malhotra A, Gregorieff A, Wrana JL, Taylor MD,Angers S, Kenney AM. YB-1 is elevated in medulloblastoma and drives proliferation in Sonic hedgehog-dependent cerebellar granule neuron progenitor cells and medulloblastoma cells. Oncogene. 2016; 35:4256-4268.

76. Fernandez-L A, Northcott PA, Dalton J, Fraga C, Ellison D, Angers S, Taylor MD, Kenney AM. YAP1 is amplified and up-regulated in hedgehog-associated medulloblastomas and mediates Sonic hedgehog-driven neural precursor proliferation. Genes Dev. 2009; 23:2729-2741.

77. Dominguez-Calderon A, Avila-Flores A, Ponce A, LópezBayghen E, Calderón-Salinas JV, Luis Reyes J, ChávezMunguía B, Segovia J, Angulo C, Ramírez L, GallegoGutiérrez H, Alarcón L,Martín-Tapia D, et al. ZO-2 silencing induces renal hypertrophy through a cell cycle mechanism and the activation of YAP and the mTOR pathway. Mol Biol Cell. 2016; 27:1581-1595.

78. Kudryashova TV, Goncharov DA, Pena A, Kelly N, Vanderpool R, Baust J, Kobir A, Shufesky W,Mora AL, Morelli AE, Zhao J, Ihida-Stansbury K, Chang B, et al. HIPPO-Integrin-linked Kinase Cross-Talk Controls Self-Sustaining Proliferation and Survival in Pulmonary Hypertension. Am J Respir Crit Care Med. 2016; 194:866-877.

79. Taniguchi K, Moroishi $\mathrm{T}$, de Jong PR, Krawczyk M, Grebbin BM, Luo H, Xu RH, Golob-Schwarzl N, Schweiger C, Wang K, Di Caro G, Feng Y, Fearon ER, et al. YAP-IL-6ST autoregulatory loop activated on APC loss controls colonic tumorigenesis. Proc Natl Acad Sci U S A. 2017; 114:1643-1648.

80. Taniguchi K, Wu LW, Grivennikov SI, de Jong PR, Lian I, Yu FX, Wang K, Ho SB, Boland BS, Chang JT, Sandborn WJ, Hardiman G, Raz E, et al. A gp130-Src-YAP module links inflammation to epithelial regeneration. Nature. 2015; 519:57-62.
81. Zhang K, Hu Z, Qi H, Shi Z, Chang Y, Yao Q, Cui H, Zheng L, Han Y, Han X, Zhang Z, Chen T, Hong W. G-protein-coupled receptors mediate omega-3 PUFAsinhibited colorectal cancer by activating the Hippo pathway. Oncotarget. 2016; 7:58315-58330. https://doi.org/10.18632/ oncotarget.11089.

82. Zhu H, Cheng X, Niu X, Zhang Y, Guan J, Liu X, Tao S, Wang Y, Zhang C. Proton-sensing GPCR-YAP Signalling Promotes Cell Proliferation and Survival. Int J Biol Sci. 2015; 11:1181-1189.

83. Totaro A, Castellan M, Battilana G, Zanconato F, Azzolin L, Giulitti S, Cordenonsi M, Piccolo S. YAP/TAZ link cell mechanics to Notch signalling to control epidermal stem cell fate. Nat Commun. 2017; 8:15206.

84. Esteves DLJ, Bonnin MA, Birchmeier C, Duprez D. Muscle contraction is required to maintain the pool of muscle progenitors via YAP and NOTCH during fetal myogenesis. Elife. 2016; 5.

85. Tumaneng K, Schlegelmilch K, Russell RC, Yimlamai D, Basnet H, Mahadevan N, Fitamant J,Bardeesy N, Camargo FD, Guan KL. YAP mediates crosstalk between the Hippo and PI(3)K-TOR pathways by suppressing PTEN via miR29. Nat Cell Biol. 2012; 14:1322-1329.

86. Avruch J, Zhou D, Bardeesy N. YAP oncogene overexpression supercharges colon cancer proliferation. Cell Cycle. 2012; 11:1090-1096.

87. Imajo M, Miyatake K, Iimura A, Miyamoto A, Nishida E. A molecular mechanism that links Hippo signalling to the inhibition of Wnt/beta-catenin signalling. EMBO J. 2012; 31:1109-1122.

88. Lapi E, Di Agostino S, Donzelli S, Gal H, Domany E, Rechavi G, Pandolfi PP, Givol D, Strano S, Lu X,Blandino G. PML, YAP, and p73 are components of a proapoptotic autoregulatory feedback loop. Mol Cell. 2008; 32:803-814.

89. Okamoto R, Tsuchiya K, Nemoto Y, Akiyama J, Nakamura T, Kanai T, Watanabe M. Requirement of Notch activation during regeneration of the intestinal epithelia. Am J Physiol Gastrointest Liver Physiol. 2009; 296:G23-G35.

90. Camargo FD, Gokhale S, Johnnidis JB, Fu D, Bell GW, Jaenisch R, Brummelkamp TR. YAP1 increases organ size and expands undifferentiated progenitor cells. Curr Biol. 2007; 17:2054-2060.

91. Zhou D, Zhang Y, Wu H, Barry E, Yin Y, Lawrence E, Dawson D, Willis JE, Markowitz SD, Camargo FD,Avruch J. Mst1 and Mst2 protein kinases restrain intestinal stem cell proliferation and colonic tumorigenesis by inhibition of Yes-associated protein (Yap) overabundance. Proc Natl Acad Sci U S A. 2011; 108:E1312-E1320.

92. Urtasun R, Latasa MU, Demartis MI, Balzani S, Goñi S, Garcia-Irigoyen O, Elizalde M, Azcona M,Pascale RM, Feo F, Bioulac-Sage P, Balabaud C, Muntané J. Connective tissue growth factor autocriny in human hepatocellular carcinoma: oncogenic role and regulation by epidermal growth factor receptor/yes-associated protein-mediated activation. Hepatology. 2011; 54:2149-2158. 
93. He C, Lv X, Hua G, Lele SM, Remmenga S, Dong J, Davis JS, Wang C. YAP forms autocrine loops with the ERBB pathway to regulate ovarian cancer initiation and progression. Oncogene. 2015.

94. Johnson R, Halder G. The two faces of Hippo: targeting the Hippo pathway for regenerative medicine and cancer treatment. Nat Rev Drug Discov. 2014; 13:63-79.

95. Vassilev A, Kaneko KJ, Shu H, Zhao Y, DePamphilis ML. TEAD/TEF transcription factors utilize the activation domain of YAP65, a Src/Yes-associated protein localized in the cytoplasm. Genes Dev. 2001; 15:1229-1241.

96. Romero-Perez L, Garcia-Sanz P, Mota A, Leskelä S, Hergueta-Redondo M, Díaz-Martín J, López-García MA, Castilla MA, Martínez-Ramírez A, Soslow RA, MatiasGuiu X, Moreno-Bueno G, Palacios J. A role for the transducer of the Hippo pathway, TAZ, in the development of aggressive types of endometrial cancer. Mod Pathol. 2015; 28:1492-1503.

97. Song S, Honjo S, Jin J, Chang SS, Scott AW, Chen Q, Kalhor N, Correa AM, Hofstetter WL, Albarracin CT, Wu TT, Johnson RL, Hung MC, Ajani JA. The Hippo Coactivator YAP1 Mediates EGFR Overexpression and Confers Chemoresistance in Esophageal Cancer. Clin Cancer Res. 2015; 21:2580-2590.

98. Tanahashi K, Natsume A, Ohka F, Motomura K, Alim A, Tanaka I, Senga T, Harada I, Fukuyama R, Sumiyoshi N, Sekido Y, Wakabayashi T. Activation of Yes-Associated Protein in Low-Grade Meningiomas Is Regulated by Merlin, Cell Density, and Extracellular Matrix Stiffness. J Neuropathol Exp Neurol. 2015; 74:704-709.

99. Oh JE, Ohta T, Satomi K, Foll M, Durand G, McKay J, Le Calvez-Kelm F, Mittelbronn M, Brokinkel B, Paulus W, Ohgaki H. Alterations in the NF2/LATS1/LATS2/YAP Pathway in Schwannomas. J Neuropathol Exp Neurol. 2015; 74:952-959.

100. Tremblay AM, Missiaglia E, Galli GG, Hettmer S, Urcia R, Carrara M, Judson RN, Thway K, Nadal G, Selfe JL, Murray G, Calogero RA, De Bari C, et al. The Hippo transducer YAP1 transforms activated satellite cells and is a potent effector of embryonal rhabdomyosarcoma formation. Cancer Cell. 2014; 26:273-287.

101. Eisinger-Mathason TS, Mucaj V, Biju KM, Nakazawa MS, Gohil M, Cash TP, Yoon SS, Skuli N, Park KM, Gerecht S, Simon MC. Deregulation of the Hippo pathway in soft-tissue sarcoma promotes FOXM1 expression and tumorigenesis. Proc Natl Acad Sci U S A. 2015; 112:E3402-E3411.

102. Ou C, Sun Z, Li X, Li X, Ren W, Qin Z, Zhang X, Yuan W, Wang J, Yu W, Zhang S, Peng Q, Yan Q, et al. MiR-590$5 \mathrm{p}$, a density-sensitive microRNA, inhibits tumorigenesis by targeting YAP1 in colorectal cancer. Cancer Lett. 2017; 399:53-63.

103. Jiang J, Chang W, Fu Y, Gao Y, Zhao C, Zhang X, Zhang S. SAV1 represses the development of human colorectal cancer by regulating the Akt-mTOR pathway in a YAPdependent manner. Cell Prolif. 2017.
104. Wierzbicki PM, Rybarczyk A. The Hippo pathway in colorectal cancer. Folia Histochem Cytobiol. 2015; 53:105-119.

105. Konsavage WJ, Kyler SL, Rennoll SA, Jin G, Yochum GS. Wnt/beta-catenin signaling regulates Yes-associated protein (YAP) gene expression in colorectal carcinoma cells. J Biol Chem. 2012; 287:11730-11739.

106. Wang L, Shi S, Guo Z, Zhang X, Han S, Yang A, Wen W, Zhu Q. Overexpression of YAP and TAZ is an independent predictor of prognosis in colorectal cancer and related to the proliferation and metastasis of colon cancer cells. PLoS One. 2013; 8:e65539.

107. Vigneron AM, Ludwig RL, Vousden KH. Cytoplasmic ASPP1 inhibits apoptosis through the control of YAP. Genes Dev. 2010; 24:2430-2439.

108. Shao DD, Xue W, Krall EB, Bhutkar A, Piccioni F, Wang X, Schinzel AC, Sood S, Rosenbluh J, Kim JW, Zwang Y, Roberts TM, Root DE et al. KRAS and YAP1 converge to regulate EMT and tumor survival. Cell. 2014; 158:171-184.

109. Wang Z, Liu P, Zhou X, Wang T, Feng X, Sun YP, Xiong Y, Yuan HX, Guan KL. Endothelin Promotes Colorectal Tumorigenesis by Activating YAP/TAZ. Cancer Res. 2017; 77:2413-2423.

110. Lamar JM, Stern P, Liu H, Schindler JW, Jiang ZG, Hynes RO. The Hippo pathway target, YAP, promotes metastasis through its TEAD-interaction domain. Proc Natl Acad Sci U S A. 2012; 109:E2441-E2450.

111. Zhang H, von Gise A, Liu Q, Hu T, Tian X, He L, Pu W, Huang X, He L, Cai CL, Camargo FD, Pu WT, Zhou B. Yap1 is required for endothelial to mesenchymal transition of the atrioventricular cushion. J Biol Chem. 2014; 289:18681-18692.

112. Li H, Wang Z, Zhang W, Qian K, Liao G, Xu W, Zhang S. VGLL4 inhibits EMT in part through suppressing Wnt/betacatenin signaling pathway in gastric cancer. Med Oncol. $2015 ; 32: 83$.

113. Diepenbruck M, Waldmeier L, Ivanek R, Berninger P, Arnold P, van Nimwegen E, Christofori G. Tead2 expression levels control the subcellular distribution of Yap and Taz, zyxin expression and epithelial-mesenchymal transition. J Cell Sci. 2014; 127:1523-1536.

114. Zhang Y, Zhou M, Wei H, Zhou H, He J, Lu Y, Wang D, Chen B, Zeng J, Peng W, Du F, Gong A, Xu M. Furin promotes epithelial-mesenchymal transition in pancreatic cancer cells via Hippo-YAP pathway. Int J Oncol. 2017; 50:1352-1362.

115. Zhao H, Huang A, Li P, Quan Y, Feng B, Chen X, Mao Z, Zhu Z, Zheng M. E2A suppresses invasion and migration by targeting YAP in colorectal cancer cells. J Transl Med. 2013; 11:317.

116. Ehsanian R, Brown M, Lu H, Yang XP, Pattatheyil A, Yan B, Duggal P, Chuang R, Doondeea J, Feller S, Sudol M, Chen Z, Van Waes C. YAP dysregulation by phosphorylation or DeltaNp63-mediated gene repression 
promotes proliferation, survival and migration in head and neck cancer subsets. Oncogene. 2010; 29:6160-6171.

117. Matallanas D, Romano D, Yee K, Meissl K, Kucerova L, Piazzolla D, Baccarini M, Vass JK, Kolch W, O'Neill E. RASSF1A elicits apoptosis through an MST2 pathway directing proapoptotic transcription by the p73 tumor suppressor protein. Mol Cell. 2007; 27:962-975.

118. Yuan M, Tomlinson V, Lara R, Holliday D, Chelala C, Harada T, Gangeswaran R, Manson-Bishop C, Smith P, Danovi SA, Pardo O, Crook T, Mein CA, et al. Yesassociated protein (YAP) functions as a tumor suppressor in breast. Cell Death Differ. 2008; 15:1752-1759.

119. Yu SJ, Hu JY, Kuang XY, Luo JM, Hou YF, Di GH, Wu J, Shen ZZ, Song HY, Shao ZM. MicroRNA-200a promotes anoikis resistance and metastasis by targeting YAP1 in human breast cancer. Clin Cancer Res. 2013; 19:1389-1399.

120. Cottini F, Hideshima T, Xu C, Sattler M, Dori M, Agnelli L, ten Hacken E, Bertilaccio MT, Antonini E, Neri A, Ponzoni M, Marcatti M, Richardson PG, et al. Rescue of Hippo coactivator YAP1 triggers DNA damage-induced apoptosis in hematological cancers. Nat Med. 2014; 20:599-606.

121. Levy D, Adamovich Y, Reuven N, Shaul Y. The Yesassociated protein 1 stabilizes $\mathrm{p} 73$ by preventing Itchmediated ubiquitination of p73. Cell Death Differ. 2007; 14:743-751.

122. Barry ER, Morikawa T, Butler BL, Shrestha K, de la Rosa R, Yan KS, Fuchs CS, Magness ST, Smits R, Ogino S, Kuo CJ, Camargo FD. Restriction of intestinal stem cell expansion and the regenerative response by YAP. Nature. 2013; 493:106-110.

123. Strano S, Monti O, Pediconi N, Baccarini A, Fontemaggi G, Lapi E, Mantovani F, Damalas A, Citro G, Sacchi A, Del Sal G, Levrero M, Blandino G. The transcriptional coactivator Yes-associated protein drives p73 gene-target specificity in response to DNA Damage. Mol Cell. 2005; 18:447-459.

124. Heath JP. Epithelial cell migration in the intestine. Cell Biol Int. 1996; 20:139-146.

125. Louvard D, Kedinger M, Hauri HP. The differentiating intestinal epithelial cell: establishment and maintenance of functions through interactions between cellular structures. Annu Rev Cell Biol. 1992; 8:157-195.

126. Potten CS, Booth C, Pritchard DM. The intestinal epithelial stem cell: the mucosal governor. Int J Exp Pathol. 1997; 78:219-243.

127. Marshman E, Booth C, Potten CS. The intestinal epithelial stem cell. Bioessays. 2002; 24:91-98.

128. Leblond CP. The life history of cells in renewing systems. Am J Anat. 1981; 160:114-158.

129. Slack JM. Stem cells in epithelial tissues. Science. 2000; 287:1431-1433.

130. Reya T, Morrison SJ, Clarke MF, Weissman IL. Stem cells, cancer, and cancer stem cells. Nature. 2001; 414:105-111.

131. Le Bouteiller M, Jensen KB. Hippo signalling directs intestinal fate. Nat Cell Biol. 2015; 17:5-6.
132. Oshima N, Yamada Y, Nagayama S, Kawada K, Hasegawa $\mathrm{S}$, Okabe H, Sakai Y, Aoi T. Induction of cancer stem cell properties in colon cancer cells by defined factors. PLoS One. 2014; 9:e101735.

133. Kim H. Clinical Implication of Colorectal Cancer Stem Cells: Still Has a Long Way to Go. Ann Coloproctol. 2015; 31:79-80.

134. Yang YM, Chang JW. Current status and issues in cancer stem cell study. Cancer Invest. 2008; 26:741-755.

135. Barker N, Ridgway RA, van Es JH, van de Wetering M, Begthel H, van den Born M, Danenberg E, Clarke AR, Sansom OJ, Clevers H. Crypt stem cells as the cells-oforigin of intestinal cancer. Nature. 2009; 457:608-611.

136. Li VS, Clevers H. Intestinal regeneration: YAP-tumor suppressor and oncoprotein? Curr Biol. 2013; 23:R110-R112.

137. Barry ER, Camargo FD. The Hippo superhighway: signaling crossroads converging on the Hippo/Yap pathway in stem cells and development. Curr Opin Cell Biol. 2013; 25:247-253.

138. Imajo M, Ebisuya M, Nishida E. Dual role of YAP and TAZ in renewal of the intestinal epithelium. Nat Cell Biol. 2015; 17:7-19.

139. Wang Y, Yu A, Yu FX. The Hippo pathway in tissue homeostasis and regeneration. Protein Cell. 2017; 8:349-359.

140. Cai J, Zhang N, Zheng Y, de Wilde RF, Maitra A, Pan D. The Hippo signaling pathway restricts the oncogenic potential of an intestinal regeneration program. Genes Dev. 2010; 24:2383-2388.

141. Lian I, Kim J, Okazawa H, Zhao J, Zhao B, Yu J, Chinnaiyan A, Israel MA, Goldstein LS, Abujarour R, Ding $\mathrm{S}$, Guan KL. The role of YAP transcription coactivator in regulating stem cell self-renewal and differentiation. Genes Dev. 2010; 24:1106-1118.

142. Patel PH, Dutta D, Edgar BA. Niche appropriation by Drosophila intestinal stem cell tumours. Nat Cell Biol. 2015.

143. Attisano L, Wrana JL. Signal integration in TGF-beta, WNT, and Hippo pathways. F1000Prime Rep. 2013; 5:17.

144. Imajo M, Miyatake K, Iimura A, Miyamoto A, Nishida E. A molecular mechanism that links Hippo signalling to the inhibition of Wnt/beta-catenin signalling. EMBO J. 2012; 31:1109-1122.

145. Clevers H. Wnt/beta-catenin signaling in development and disease. Cell. 2006; 127:469-480.

146. Kafka A, Basic-Kinda S, Pecina-Slaus N. The cellular story of dishevelleds. Croat Med J. 2014; 55:459-467.

147. Wynshaw-Boris A. Dishevelled: in vivo roles of a multifunctional gene family during development. Curr Top Dev Biol. 2012; 101:213-235.

148. Rajakariar R, Newson J, Jackson EK, Sawmynaden P, Smith A, Rahman F, Yaqoob MM, Gilroy DW. Nonresolving inflammation in gp91phox-/- mice, a model of human chronic granulomatous disease, has lower adenosine and cyclic adenosine 5'-monophosphate. J Immunol. 2009; 182:3262-3269. 
149. Mantovani A. Cancer: Inflaming metastasis. Nature. 2009; 457:36-37.

150. Hussain SP, Harris CC. Inflammation and cancer: an ancient link with novel potentials. Int J Cancer. 2007; 121:2373-2380.

151. Schetter AJ, Heegaard NH, Harris CC. Inflammation and cancer: interweaving microRNA, free radical, cytokine and p53 pathways. Carcinogenesis. 2010; 31:37-49.

152. Woods DC, White YA, Dau C, Johnson AL. TLR4 activates NF-kappaB in human ovarian granulosa tumor cells. Biochem Biophys Res Commun. 2011; 409:675-680.

153. Liu J, Xu D, Wang Q, Zheng D, Jiang X, Xu L. LPS induced miR-181a promotes pancreatic cancer cell migration via targeting PTEN and MAP2K4. Dig Dis Sci. 2014; 59:1452-1460.

154. Wlasiuk P, Tomczak W, Zajac M, Dmoszyńska A, Giannopoulos K. Total expression of HLA-G and TLR-9 in chronic lymphocytic leukemia patients. Hum Immunol. 2013; 74:1592-1597.

155. Demoulin S, Herfs M, Delvenne P, Hubert P. Tumor microenvironment converts plasmacytoid dendritic cells into immunosuppressive/tolerogenic cells: insight into the molecular mechanisms. J Leukoc Biol. 2013; 93:343-352.

156. Severa M, Giacomini E, Gafa V, Anastasiadou E, Rizzo F, Corazzari M, Romagnoli A, Trivedi P, Fimia GM, Coccia EM. EBV stimulates TLR- and autophagy-dependent pathways and impairs maturation in plasmacytoid dendritic cells: implications for viral immune escape. Eur J Immunol. 2013; 43:147-158.

157. Mantovani A, Allavena P, Sica A, Balkwill F. Cancer-related inflammation. Nature. 2008; 454:436-444.

158. Colotta F, Allavena P, Sica A, Garlanda C, Mantovani A. Cancer-related inflammation, the seventh hallmark of cancer: links to genetic instability. Carcinogenesis. 2009; 30:1073-1081.

159. Hanahan D, Weinberg RA. Hallmarks of cancer: the next generation. Cell. 2011; 144:646-674.

160. Zhang X, Ai F, Li X, She X, Li N, Tang A, Qin Z, Ye Q, Tian L, Li G, Shen S, Ma J. Inflammation-induced S100A8 activates Id 3 and promotes colorectal tumorigenesis. Int $\mathrm{J}$ Cancer. 2015.

161. Ai F, Zhang X, Li X, Qin Z, Ye Q, Tian L, Tang A, Li N, Li G, Ma J, Shen S. Up-regulation of matrix metalloproteinases in a mouse model of chemically induced colitis-associated cancer: the role of microRNAs. Oncotarget. 2015; 6:5412-5425. https://doi.org/10.18632/ oncotarget.3027.

162. Tang A, Li N, Li X, Yang H, Wang W, Zhang L, Li G, Xiong W, Ma J, Shen S. Dynamic activation of the key pathways: linking colitis to colorectal cancer in a mouse model. Carcinogenesis. 2012; 33:1375-1383.

163. Yamada D, Rizvi S, Razumilava N, Bronk SF, Davila JI, Champion MD, Borad MJ, Bezerra JA, Chen X, Gores GJ. IL-33 facilitates oncogene-induced cholangiocarcinoma in mice by an interleukin-6-sensitive mechanism. Hepatology. 2015; 61:1627-1642.
164. Li J, Razumilava N, Gores GJ, Walters S, Mizuochi T, Mourya R, Bessho K, Wang YH, Glaser SS, Shivakumar P, Bezerra JA. Biliary repair and carcinogenesis are mediated by IL-33-dependent cholangiocyte proliferation. J Clin Invest. 2014; 124:3241-3251.

165. Naugler WE, Karin M. NF-kappaB and cancer-identifying targets and mechanisms. Curr Opin Genet Dev. 2008; 18:19-26.

166. Atreya I, Atreya R, Neurath MF. NF-kappaB in inflammatory bowel disease. J Intern Med. 2008; 263:591-596.

167. Gao Y, Wang Y, Feng J, Feng G, Zheng M, Yang Z, Xiao Z, Lu Z, Ye L, Zhang X. A hairpin within YAP mRNA 3'UTR functions in regulation at post-transcription level. Biochem Biophys Res Commun. 2015; 459:306-312.

168. Huang Z, Wang Y, Hu G, Zhou J, Mei L, Xiong WC. YAP Is a Critical Inducer of SOCS3, Preventing Reactive Astrogliosis. Cereb Cortex. 2016; 26:2299-2310.

169. Zhang B, Gong A, Shi H, Bie Q, Liang Z, Wu P, Mao F, Qian $\mathrm{H}, \mathrm{Xu}$ W. Identification of a novel YAP-14-3-3zeta negative feedback loop in gastric cancer. Oncotarget. 2017; 8:71894-71910. https://doi.org/10.18632/oncotarget.18011.

170. Wu H, Liu Y, Jiang XW, Li WF, Guo G, Gong JP, Ding $X$. Clinicopathological and prognostic significance of Yesassociated protein expression in hepatocellular carcinoma and hepatic cholangiocarcinoma. Tumour Biol. 2016; 37:13499-13508.

171. Su LL, Ma WX, Yuan JF, Shao Y, Xiao W, Jiang SJ. Expression of Yes-associated protein in non-small cell lung cancer and its relationship with clinical pathological factors. Chin Med J (Engl). 2012; 125:4003-4008.

172. Sun Z, Xu R, Li X, Ren W, Ou C, Wang Q, Zhang H, Zhang X, Ma J, Wang H, Li G. Prognostic Value of Yes-Associated Protein 1 (YAP1) in Various Cancers: A Meta-Analysis. PLoS One. 2015; 10:e135119.

173. Liang K, Zhou G, Zhang Q, Li J, Zhang C. Expression of hippo pathway in colorectal cancer. Saudi J Gastroenterol. 2014; 20:188-194.

174. Lee KW, Lee SS, Kim SB, Sohn BH, Lee HS, Jang HJ, Park YY, Kopetz S, Kim SS, Oh SC, Lee JS. Significant association of oncogene YAP1 with poor prognosis and cetuximab resistance in colorectal cancer patients. Clin Cancer Res. 2015; 21:357-364.

175. Wang Y, Xie C, Li Q, Xu K, Wang E. Clinical and prognostic significance of Yes-associated protein in colorectal cancer. Tumour Biol. 2013; 34:2169-2174.

176. Kim SK, Jung WH, Koo JS. Expression of Yes-associated protein (YAP) in breast phyllodes tumor. Int J Clin Exp Pathol. 2014; 7:5997-6005.

177. Basu D, Lettan R, Damodaran K, Strellec S, Reyes-Mugica M, Rebbaa A. Identification, mechanism of action, and antitumor activity of a small molecule inhibitor of hippo, TGF-beta, and Wnt signaling pathways. Mol Cancer Ther. 2014; 13:1457-1467.

178. Fan F, He Z, Kong LL, Chen Q, Yuan Q, Zhang S, Ye J, Liu H, Sun X, Geng J, Yuan L, Hong L, Xiao C, et al. 
Pharmacological targeting of kinases MST1 and MST2 augments tissue repair and regeneration. Sci Transl Med. 2016; 8:108r-352r.

179. Anand R, Maksimoska J, Pagano N, Wong EY, Gimotty PA, Diamond SL, Meggers E, Marmorstein R. Toward the development of a potent and selective organoruthenium mammalian sterile 20 kinase inhibitor. J Med Chem. 2009; 52:1602-1611.

180. Yu FX, Zhao B, Panupinthu N, Jewell JL, Lian I, Wang LH, Zhao J, Yuan H, Tumaneng K, Li H, Fu XD, Mills GB, Guan KL. Regulation of the Hippo-YAP pathway by G-proteincoupled receptor signaling. Cell. 2012; 150:780-791.

181. Deng Y, Matsui Y, Pan W, Li Q, Lai ZC. Yap1 plays a protective role in suppressing free fatty acid-induced apoptosis and promoting beta-cell survival. Protein Cell. 2016; 7:362-372.

182. Pathak MM, Nourse JL, Tran T, Hwe J, Arulmoli J, Le DT, Bernardis E, Flanagan LA, Tombola F. Stretch-activated ion channel Piezo1 directs lineage choice in human neural stem cells. Proc Natl Acad Sci U S A. 2014; 111:16148-16153.

183. Chen J, Harris RC. Interaction of the EGF Receptor and the Hippo Pathway in the Diabetic Kidney. J Am Soc Nephrol. 2016; 27:1689-1700.

184. Lin CH, Pelissier FA, Zhang H, Lakins J, Weaver VM, Park C, LaBarge MA. Microenvironment rigidity modulates responses to the HER2 receptor tyrosine kinase inhibitor lapatinib via YAP and TAZ transcription factors. Mol Biol Cell. 2015; 26:3946-3953.

185. Oudhoff MJ, Freeman SA, Couzens AL, Antignano F, Kuznetsova E, Min PH, Northrop JP, Lehnertz B, BarsyteLovejoy D, Vedadi M, Arrowsmith CH, Nishina H, Gold MR, et al. Control of the hippo pathway by Set7-dependent methylation of Yap. Dev Cell. 2013; 26:188-194.

186. Brodowska K, Al-Moujahed A, Marmalidou A, Meyer Zu Horste M, Cichy J, Miller JW, Gragoudas E, Vavvas DG. The clinically used photosensitizer Verteporfin (VP) inhibits YAP-TEAD and human retinoblastoma cell growth in vitro without light activation. Exp Eye Res. 2014; 124:67-73.

187. Jiao S, Wang H, Shi Z, Dong A, Zhang W, Song X, He F, Wang Y, Zhang Z, Wang W, Wang X, Guo T, Li P. A peptide mimicking VGLL4 function acts as a YAP antagonist therapy against gastric cancer. Cancer Cell. 2014; 25:166-180.

188. Touil Y, Igoudjil W, Corvaisier M, Dessein AF, Vandomme J, Monté D, Stechly L, Skrypek N, Langlois C, Grard G, Millet G, Leteurtre E, Dumont P. Colon cancer cells escape 5FU chemotherapy-induced cell death by entering stemness and quiescence associated with the c-Yes/YAP axis. Clin Cancer Res. 2014; 20:837-846.

189. Wang Z, Wu Y, Wang H, Zhang Y, Mei L, Fang X, Zhang X, Zhang F, Chen H, Liu Y, Jiang Y, Sun S, Zheng Y, et al. Interplay of mevalonate and Hippo pathways regulates RHAMM transcription via YAP to modulate breast cancer cell motility. Proc Natl Acad Sci U S A. 2014; 111:E89-E98.

190. Wang DY, Wu YN, Huang JQ, Wang W, Xu M, Jia JP, Han G, Mao BB, Bi WZ. Hippo/YAP signaling pathway is involved in osteosarcoma chemoresistance. Chin J Cancer. 2016; 35:47.

191. Park GS, Oh H, Kim M, Kim T, Johnson RL, Irvine KD, Lim DS. An evolutionarily conserved negative feedback mechanism in the Hippo pathway reflects functional difference between LATS1 and LATS2. Oncotarget. 2016; 7:24063-24075. https://doi.org/10.18632/oncotarget.8211.

192. Moroishi T, Park HW, Qin B, Chen Q, Meng Z, Plouffe SW, Taniguchi K, Yu FX, Karin M, Pan D, Guan KL. A YAP/TAZ-induced feedback mechanism regulates Hippo pathway homeostasis. Genes Dev. 2015; 29:1271-1284.

193. Diamantopoulou Z, White G, Fadlullah M, Dreger M, Pickering K, Maltas J, Ashton G, MacLeod R, Baillie GS, Kouskoff V, Lacaud G, Murray GI, Sansom OJ, et al. TIAM1 Antagonizes TAZ/YAP Both in the Destruction Complex in the Cytoplasm and in the Nucleus to Inhibit Invasion of Intestinal Epithelial Cells. Cancer Cell. 2017; 31:621-634.

194. Sayedyahossein S, Li Z, Hedman AC, Morgan CJ, Sacks DB. IQGAP1 Binds to Yes-associated Protein (YAP) and Modulates Its Transcriptional Activity. J Biol Chem. 2016; 291:19261-19273.

195. Azzolin L, Piccolo S. A TIAM Double Hit to Oppose YAP/ TAZ. Cancer Cell. 2017; 31:607-608. 